\title{
EDUCATIONAL
} TECHNOLOGY

\section{Reflections on educational technology in Victorian State post-primary schools}

\author{
William Rey \\ Maribyrnong High School/ Pt Gellibrand High School
}

\begin{abstract}
This article presents a brief account of the current role of educational technology in Victorian secondary schools. Examples and discussion are drawn from the authors own experience and those of two colleagues (Paul Chevchuk and Andrew Lecky), all of whom are practising educational technologists in Victorian Post-Primary Schools.
\end{abstract}

Technological advances abound in today's world. People can marvel when reflecting back to a recent past without home video, personal microcomputers and all the paraphernalia of the information technology explosion. To survive in this technological world Australians are being urged to participate in the changes and to develop their own technological industries. AUSSAT is supposed to show that it is possible.

A requirement of such survival is to become aware of and to understand this new technological society. Schools are being urged to teach students to cope with technology and to incorporate new technology into the curriculum and teaching methods. To quote from the preface of the 1985 Report of the Australian Education Council Task Force on Education and Technology, "the education system must adapt to new demands and possibilities in such a way as to enable Australians to exploit the benefits and opportunities offered by new technologies, while ensuring that social needs are met and the potential of individuals is maximised in a time of rapid change, uncertainty and limited resources."

One would assume that educational technology would be at the forefront in assisting schools to adapt in this way. At the state post-primary school level in Victoria, the history of educational technologists can be likened to 
that of a person staggering down a road, taking two steps forward and one step back before suddenly stumbling up a blind alley. Occasionally an opening appears leading to a new road.

Educational Technologists in post-primary schools were usually teachers who had an interest in things audio-visual or who, by force of circumstances in their schools, assisted with audio-visual services. They undertook studies in Educational Technology to learn more about the work they were doing and to gain formal qualifications. Some were able to gain recognition from the education department for full-time study leave, others did it in their own time as part-time students.

There were never very many of these teachers. Most were from technical schools and these were destined to go to the Educational Technology departments of the TAFE colleges. Teachers from secondary school, by and large returned to their schools, though not as educational technologists. They usually took charge of the school's audio visual department.

The 1981 group of educational technology trainees was something of an exception for it included the largest and the last group of secondary school teachers on full-time educational technology study leave. At the end of the course, contrary to the norm, six of these teachers were given positions in secondary schools as educational technologists. Moreover, they were too much in demand to be used in just one school. Therefore each was to be shared by two schools and one got to work in three schools.

The road seemed straight and the way clear at that time. Yet only two of us are now left. No further graduates came to keep the momentum going. The others found the openings in the blind alley. Some post primary educational technologists have had their audio visual resource positions gradually eliminated. This was an easy way out of staffing problems for their schools. Certainly easier than declaring English or Mathematics teachers in excess!

Others became frustrated with the lack of prospects for advancement and opted to return to the classroom. Possibly, this would help them to qualify for a senior teacher promotion. They certainly could not do this as an educational technologist. A few others found the way to advancement lay outside the post-primary school system, in TAFE, tertiary institutions or regional offices.

Did the schools really know what they were getting? One problem was that of role definition and that was a task the 1981 group of post secondary educational technologists were given on return to schools. Clearly, we 
failed in this. I, and probably others, first tried to establish my role according to the ASET definition. This was too abstract and too easy to ignore.

Then, I tried to show how it was different from the role of others working in the audio visual area in schools. In 1983, I wrote an article to this effect in a Western Metropolitan Regional Newsletter and called for a meeting of all the different types of audio-visual school personnel. The newsletter editor, who supported this idea, called for a response from those whose role in school was that of an educational technologist. Not surprisingly, as far as I know, no one answered the call. There was certainly no such meeting.

Educational Technology - it seems an incredibly difficult word for educators, communicators and administrators. Even after five years whenever I am introduced in school by position, it is with a sense of wonder or confusion. It seems a rather grandiose title for the audio visual aide/technician. That is the easy and natural assumption for people in school to make about someone in my position. After all, that is what they want. Someone who runs the audio visual department, collects the films, sets up the video, repairs the equipment, shows you how to use the slide projector, finds the money to buy the audio-visual kit, helps with the photography class, finds that video program, explains about the latest video camera and so on. The irony is that a teacher with educational technology training is probably the person who can best attempt to single handedly cope with the impossible job.

While perhaps going beyond the prescribed role, I feel, by and large, educational technologists have made a very valuable contribution to post primary schools. They have generally helped to develop the many services offered by the school's resources facilities, an area prone to inefficiency, waste and easily run down through neglect.

It is impossible for me to cope with all the demands made by my schools, given a part-time position and very limited assistance. Yet, I believe my services have been appreciated over the past five years. Both school administrations profess to wanting me there full time if possible. So, why do I feel as if I am a luxury item in the life of the school ? This is not a feeling shared by classroom teachers or librarians.

Former students and their parents have expressed appreciation of my teaching ability. Why then do I get the impression that some of my colleagues regard me as a refugee from the classroom who has found a safe haven in the audio visual room? 
At present, educational technology in the post-primary school level is going nowhere. Post-primary schools do not have the resources, in either materials or personnel, to support anything like educational technology units on the TAFE model. I can not see much hope of their ever having such resources.

I believe it is necessary, as it has been for years, to take stock of the way in which technology is used and supported in education. Without a clearly defined policy and support structures for this purpose, post primary schools will not be able to effectively manage new technology. Especially at a time of uncertainty and limited resources. Without clear and obvious education department recognition and support, educational technology will not be able to survive let alone to help post-primary schools.

As I did in 1981 when I first submitted such a proposal to the education department, I still feel that what is needed is the development of a coherent audio visual/educational technology support structure for schools.

Teacher centres and computer centres have recently been developed. In my region at least, they seem to be separate and scattered and in need of more support and development. I would like to know if an overall support service policy exists and whether and in what form it recognises the need for educational technology.

I think it would be worthwhile to investigate the possibility of developing a central educational technology organisation along the lines of the Council for Educational Technology in the United Kingdom. Such a central body would act as a development agency, trying to anticipate developments years in the future, defining desirable advances and showing how these could be achieved, at what cost and with what effect.

Regional centres, combinations of audio visual, educational technology and computer units, would provide the link to schools. These centres would offer a host of necessary support services to schools. They would hopefully improve the way teachers use the technology in schools. As well, they could assist schools in keeping up to date with new technologies.

Some sort of recognition is needed for the role that educational technology can play in post-primary education and some sort of support structure is needed in which it can develop. Without this, there will soon be no one left to stagger down the road. Even the blind alley will be empty. 


\section{Reference}

Arnold, L.M.F. (Chairperson). (1985). Education and Technology: Report of the Australian Education Council Task Force on Education and Technology.

Melbourne: Australian Education Council.

Please cite as: Rey, W. (1986). Reflections on educational technology in

Victorian State post-primary schools. Australian Journal of Educational

Technology, 2(1), 13-17. http: / / www.ascilite.org.au/ajet/ajet2/rey.html 